Pamiętnik Literacki 2012, 4, s. 7-17
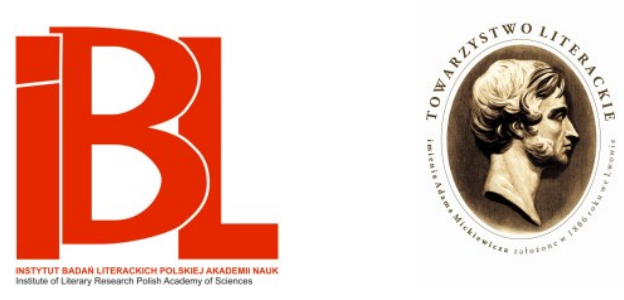

\title{
O kilku przypadkach bowaryzmu zbiorowego
}

\author{
Arnold Van Gennep
}

Tłum. Zuzanna Krasnopolska 


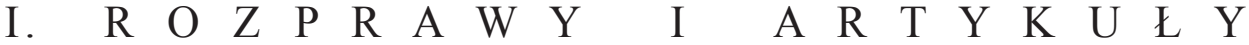 \\ Pamiętnik Literacki CIII, 2012, z. 4 PL ISSN 0031-0514}

\section{ARNOLD VAN GENNEP}

\section{O KILKU PRZYPADKACH BOWARYZMU ZBIOROWEGO*}

Dzięki Jules'owi de Gaultierowi ${ }^{1}$, twórcy terminu i teoretykowi fenomenu, przez „,bowaryzm” rozumiemy „zdolność człowieka do postrzegania siebie innym, niż się jest w rzeczywistości”. Istnieje bowaryzm indywidualny i bowaryzm zbiorowy. Ten ostatni został wyróżniony przez Gaultiera, który przeprowadził analizę społeczeństw europejskich, zarówno tych współczesnych i nowożytnych, jak $i$ antycznych ${ }^{2}$. Jednakże autor wielokrotnie powtarzał ${ }^{3}$, że studium owego fenomenu psychologicznego, po to by stać się teorią kompletną i pokazać wyraźnie jej wkład społeczny, powinno uwzględniać wszystkie grupy ludzkie wywodzące się z każdej epoki i należące do każdej rasy.

Dla mieszkańców tego samego kraju zwyczaj jest zasadą jednakowej sugestii. Podobnie jak wrażliwości, na które oddziałuje ta sugestia, nawet jeśli spokrewnione, są dalekie od bycia identycznymi, badanie różnych zwyczajów pozwala odkryć źródło bogatego bowaryzmu, o ile, rzecz jasna, można dla każdego zwyczaju sporządzić zbiór indywidualnych przypadków. Poprzestajemy na zasygnalizowaniu tego działu dociekań psychologicznych, który mógłby zostać wyczerpany jedynie przez wnikliwe studia.

Bez wątpienia - brakuje wszakże metod do przeprowadzenia tego badania. Dopóki chodzi tylko o współobywateli, przy odrobinie uwagi każdemu może się udać ocenić wpływ, jaki wywiera na osobnika powszechnie podzielana idea ogólna. Codzienne życie przynosi nam, postrzegane przez tysiące ludzi, fakty, w których łatwo jest stwierdzić ich cechy dominujące. Zauważmy, że fakty - które dostarczyły Gaultierowi najbardziej wyraźnych przykładów bowaryzmu, w postaci Flauberta i Barrèsa - miały miejsce w Normandii lub Lotaryngii i w Paryżu.

* Tekst ten, w wersji oryginalnej zatytułowany De quelques cas de bovarysme collectif, ukazał się w czasopiśmie „Mercure de France” (1908, nr z 16 V).

Przypisy - jeżeli nie zaznaczono tego inaczej - pochodzą od autora. Wszystkie cytowane fragmenty podaję we własnym przekładzie. Uwagi w nawiasach kwadratowych w przypisach autora pochodzą od tłumaczki lub od redakcji. [Przypis tłum.].

1 Le Bovarysme [Paris 1902]; La Fiction universelle [t. 1, Paris 1903]; Les Raisons de l'idéalisme [t. 1, Paris 1906]; La Dépendance de la morale et l'indépendance des mœurs [Paris 1904]. 4 tomy, Societé du Mercure de France.

2 Por. Le Bovarysme de l'histoire, „Mercure de France” z 15 kwietnia i „Revue des Idées” z 15 kwietnia 1908, s. 377-383, w związku z Niewczesnymi rozważaniami [F.] N i e t z s c h e g o $\mathrm{i}$,sensem historycznym” zastosowanym wobec rozwoju społeczeństw.

3 Głównie w Le Bovarysme, s. 76, 96, 111 n., 236 n. 
To w Paryżu bowaryzm uwydatnia się jako fenomen powszechny, w którego ramach najlepiej wyodrębniają się niuanse indywidualne. Spotykamy go również w Marsylii, gdzie populacja Metysów wyraża się poprzez uderzająco bowarystyczną politykę. Jednak na wsiach francuskich, poza środowiskiem burżuazji, zmiennym i rozdartym między ekstremami, bowaryzm jest mniej skomplikowany, mniej systematyczny, mniej widoczny.

Przeciętny Francuz jest zmuszony kreślić coś na kształt pięter na różnej wysokości, na których badanie stanie się ułatwione mniej lub bardziej. Będzie mógł oceniać inne kraje tylko poprzez bardzo ogólne zarysy: wzajemne relacje systemów filozoficznych, estetycznych, politycznych i religijnych dostarczą mu elementów odmiennej precyzji w celu zdefiniowania tylko w przybliżeniu bowaryzmu uniwersalnego.

Parę lat temu widziałem z bliska dość wyraźny przypadek bowaryzmu zbiorowego w Polsce, nie rozumiejąc jeszcze jego prawdziwego znaczenia. Koncepcja arystokratyczna - choć prawidłowym określeniem byłoby raczej: „rycerska” walczy z koncepcją nie tyle niedemokratyczną, ile ze ściśle rolniczą, wiejską, a obie działają zgodnie, by zdusić lub zasymilować inną, formującą się koncepcję drobnomieszczaństwa. Dwie pierwsze frakcje są rodzime, w takim sensie, że rolnicza jest bezpośrednim, wiekowym i nieprzerwanym produktem konkretnej grupy i składa się z członków wybranych spośród niej samej; a koncepcja rycerska, mimo iż oryginalnie sprowadzona z zagranicy, z Europy Srodkowej i Rusi, jest już tak starej daty, że stała się nierozłącznym elementem polskiej arystokracji. Koncepcję drobnomieszczaństwa sprowadzono do Polski niedawno: tworzy się w mieszczańskich społecznościach żydowskich, polskich i zagranicznych (przemysłowcy i kupcy niemieccy, belgijscy, francuscy itp.) i służy za cel dla bogacących się chłopów i dla ubożejącej arystokracji.

Kilka lat temu - szczegółowa analiza konfliktów jest bardziej skomplikowana - Polacy byli podzieleni na trzy grupy, które z przyczyn bezpośrednich, a zwłaszcza ekonomicznych, usiłowały narzucić wszystkim swoją wizję rzeczywistości i społeczności, wizję iluzjonistyczną [illusionniste]. Z psychologicznego punktu widzenia rzucającym się w oczy elementem było odmienne w grupach pojęcie i poczucie h o n o r u. Obecne walki uwydatniły konflikt, nowe prądy zaś - autonomistyczny z jednej, a socjalistyczny z drugiej strony - jeszcze go skomplikowały.

Okazuje się zatem, że dla zrozumienia szerokiego pola badań, o którym mówi Gaultier, konieczne jest spełnienie kilku warunków wzajemnie się wykluczających: warunków istnienia wyraźnych kontrastów między różnymi i licznymi walkami, dzisiejszymi konfliktami ekonomicznymi, politycznymi oraz minionymi konfliktami filozoficznymi i estetycznymi. W tym sensie kraje Starego Świata dostarczają przystępnego przedmiotu oceny i analizy.

Wydawałoby się, nawet nie wychodząc poza Stary Świat, że trudność poszukiwań rośnie wraz z prostotą środowisk, w których zachowania i reakcje są mniej silne, mniej liczne oraz mniej zawiłe. Aby przekonać się, czy tak jest naprawdę, należałoby zdefiniować np. specyficzny bowaryzm Bretończyków bądź Basków. W Europie znajduje się wiele małych grup, które uważają się za inne i chcą być odmienne od pobliskich skupisk ludności. Austro-Węgry i Rosja, regiony Kaukazu: tak wiele fragmentów mozaiki składającej się na jeden region. 
Pozostają inne niezliczone grupy na różnych etapach cywilizacji materialnej i rozwoju intelektualnego. Między tymi wszystkimi grupami zachodzi wiele interakcji: ciągłej asymilacji lub odrzucania „obcych” zwyczajów przez jedną z nich. W tym przypadku określenie „obce” ma wąskie znaczenie. Dla jednego plemienia obce będzie plemię graniczne, które posługuje się odmiennym dialektem; dla jednego klanu będzie obcy, mimo ich pokrewieństwa i tego samego dialektu, drugi klan, z którym małżeństwo jest nie tyle dozwolone, co wręcz nakazane, przeciwnie niż w jakimkolwiek innym klanie (reguła egzogamii). W niedawno wydanej książ$\mathrm{ce}^{4}$ podjąłem się próby określenia mechanizmu modyfikacji społecznych wśród plemion stosunkowo prymitywnych (środkowej Australii), mało licznych i mało podatnych na wpływy zewnętrzne, tzn. pozaaustralijskie. Ukazałem, jak te modyfikacje były, z jednej strony, dziełem jednostek, wyraźnie ,zindywidualizowanych”, znanych z wyróżniającej się osobowości, daru poetyckiego, pamięci, siły inwencji religijnej i prawnej; a z drugiej strony - przedstawiłem wynik interakcji zachodzącej wewnątrz tej samej dużej grupy (plemienia lub grupy plemion) między sąsiadującymi klanami. W tych regionach granicznych, w geograficznym i socjologicznym znaczeniu tego słowa, następuje proces wzajemnego przystosowania się zwyczajów przeciwnych lub po prostu różnych. Co pewien czas rady starców dyskutują na temat zmian wprowadzonych w zwyczajach, następnie odrzucają lub przyjmują je i sprawiają w ten sposób, że stają się one obowiązujące dla całej zainteresowanej wspólnoty. Wystarczająco dogłębna analiza społeczności australijskich - na dzień dzisiejszy najbardziej prymitywnych - wskazuje na dwutorowy proces zachodzący w ewolucji społecznej: proces inwencji indywidualnej i asymilacji zbiorowej.

Nacisk wywierany na regiony przygraniczne ma dla każdego z klanów wymiar „obcego" działania. Jeśli się pójdzie dalej tym tropem i weźmie pod uwagę całą ludzkość, to się zobaczy, że co należy do klanu, należy również do plemienia, grup plemion, ludu czy nacji.

Zasada ta będzie obowiązywać też każdy z procesów twórczych z osobna. Przykładem może być formowanie się wspólnego języka, np. francuskiego, poprzez asymilację różnych elementów pochodzących z języków specjalistycznych, technicznych, gwar, języka dziecięcego itp., naturę i mechanizm tego procesu przedstawił niedawno Meillet ${ }^{5}$. Dogodne będzie również pokazanie, w jaki sposób zwyczaj powszechny tworzy się poprzez integrację bądź sukcesywne odrzucanie elementów pożyczonych od zwyczajów szczególnych; wreszcie jak katolicyzm przyjął pogańskie obrzędy wschodnie, greckie, italskie, germańskie, etc.; jak rytuał rzymskokatolicki staje się rezultatem włączenia rytuałów diecezjalnych, jak te ostatnie zachowały część oryginalności, będąc i tak podporządkowane przenikaniu się obrzędów rzymskich; jak, jednym słowem, rytuał katolicki jako całość przez wieki żył z zapożyczeń i odrzuceń, aby osiągnąć swój obecny kształt, który dąży do jedności, a zatem do skostnienia.

A jeśli rozszerzymy jeszcze wizję, jeśli spróbujemy wywołać wszystkie większe i mniejsze transformacje ludzkości, od jej początków i we wszystkich grupach, zobaczymy, jak się zderzają, łączą, mieszają, gromadzą, neutralizują wierzenia, zwyczaje, procesy twórcze, zmienione poprzez niekończący się niepokój, którego

Mythes et légendes d'Australie [Études d'ethnographie et de sociologie. Paris], 1906.

A. M e ille t, Comment les noms changent de sens. „Année Sociologique” 1907. 
sens bytu wydaje się z początku niezrozumiały do tego stopnia, że wierzymy, iż zależy on jedynie od przypadku. Po dokładnej analizie musimy przecież odrzucić wyjaśnienie dotyczące „użyteczności” materialnej. Porażka teorii ,ekonomicznej” jest ostateczna. Co do teorii ,socjologicznej” - ona tylko ustala, ale nie tłumaczy. Trzeba zatem zbadać teorię iluzjonistyczną Gaultiera. Być może, sprawi ona, że stanie się zrozumiały aspekt złożonej ewolucji społeczeństw; być może, ułatwi wyodrębnienie zasadniczych cech i, w konsekwencji, doprowadzi do sformułowania praw. Nie mamy jednak śmiałości żywić takiej nadziei, ponieważ nadal pozostaje zbyt wiele niewiadomych: nieznane szczegóły nie tylko większości czynności (zwyczajów, rytuałów), ale zwłaszcza przedstawień (wierzeń i koncepcji); badania nad psychologią człowieka, w szerokim tego słowa znaczeniu, dopiero co się rozpoczęły. Nawet studium nad psychologią Europejczyka jest jeszcze mało zaawansowane! Jeśli stworzymy abstrakcję ze wszystkich informacji zdeformowanych poprzez zastosowanie europejskich, głównie zaś chrześcijańskich, punktów widzenia wobec ,dzikich”, pozostanie nam niewiele użytecznych dokumentów, a wśród nich zwłaszcza badania psychologii eksperymentalnej, pokazujące mechanizmy, ale nie rezultaty. Tak więc fakty, które pozwoliłyby zastosować punkt widzenia Gaultiera, są nadal rzadkie, a to z dwóch powodów: szczególnej perspektywy i specjalizacji badaczy. Jedynym wyraźnym i dobrze opisanym przypadkiem bowaryzmu zbiorowego nieeuropejskiego, który odnalazłem ${ }^{6}$, jest bowaryzm zbiorowy Murzynów z Republiki Liberii, nad Zatoką Gwinejską.

Badacz Maurice Delafosse ${ }^{7}$ przed udaniem się do Liberii w roli konsula francuskiego spędził kilka lat pomiędzy ,niecywilizowanymi” Murzynami, w szczególności wśród plemion Kru, Baoulé, Agni itp. Włada on tuzinem dialektów lokalnych; jest obdarzony zmysłem komparatystycznym, zdolnością wnikliwej obserwacji i precyzyjnym stylem. Co więcej, ma rzadki, a niezbędny wśród etno-

6 W cytowanym artykule pt. Le Bovarysme de l'histoire G a u 1 t i e r nawiązuje do Polinezyjczyków opisanych przez Maxa Anély'ego: jest to jednak dokument bardziej literacki niż naukowy. Maorysi z Nowej Zelandii lepiej nadawaliby się do badań nad bowaryzmem, niektórzy z nich bowiem z zadziwiającą łatwością przejęli cywilizację europejską, w tym parlamentaryzm. Nie śmiałem przytoczyć przypadku Japończyków, o których często mówiono błędnie: zdaje mi się, że jeśli naszej cywilizacji udało się tak szybko zapuścić korzenie w tym kraju, jest to zasługa tożsamości psychologicznych, do niedawna utajonych, które wyszły już raz na jaw w japońskim życiu społecznym w okresie między XV a XVII wiekiem, tożsamości paralelnych z tożsamościami organizacyjnymi (feudalizm itp.); ale wreszcie ani Lacfadio Hearn [literówka van Gennepa; L a f c a d i o H e a r n (1850-1904), pół-Anglik i pół-Grek z pochodzenia, urodzony na Leukadzie (Lefkás), z czasem przyjął obywatelstwo japońskie i stał się największym badaczem kultury japońskiej tamtego okresu - uwaga tłum.], ani tym bardziej większość Europejczyków nie wydają się odpowiedni, by przeprowadzić wiarygodne studia nad japońskim bowaryzmem. Przypadek Indian amerykańskich, przytaczany przez G a u lt i e r a (Le Bovarysme, s. 241), jest tematem delikatnym: m.in. Czirokezom nie zagraża wyginięcie; a przede wszystkim, jaki jest pierwotny bowaryzm Indian amerykańskich? Różny czy nie od bowaryzmu anglosaskiego, tak bardzo religijnego? Murzyni Stanów Zjednoczonych i Antyli dają powody do obserwacji (humanitaryzm, prawa człowieka, itp.), nie mam jednak wystarczającej liczby dokumentów, aby prześledzić z bliska szok związany z zamierzonymi iluzjami i koniecznymi rzeczywistościami.

7 Por. Maurice D e la fo s s e: Un État Nègre, la république de Libéria, publication [Bulletin] du Comité de l'Afrique Française, [,Renseignements Coloniaux et Document” 9] 1900; Les Libériens et les Baoulé, Nègres dits civilisés et Nègres dits sauvages, fragment czasopisma „Les Milieux et les Races" 1901 [avril - may]; [R.] Vill a m u r i [M.] D e l a fo s s e, Les Coutumes Agni. Paris 1904; D e la fo s s e, Les Frontières de la Côte d'Or, de la Côte d'Ivoire et du Soudan. Paris 1908, etc. 
grafów, dar: umie rozdwoić swoją osobowość; kto nie potrafi lub nie jest w stanie się rozdwoić, przeinacza. Nie mogliśmy pominąć tej cechy, ponieważ szczególnie w etnografii „krytyka świadka” jest równie konieczna jak samo świadectwo.

Republika Liberii znajduje się nad Zatoką Gwinejską, między angielską kolonią Sierra Leone a kolonią francuską Wybrzeża Kości Słoniowej; rozciąga się de facto wzdłuż wybrzeża o długości 10 kilometrów, całe wnętrze kraju jest zajęte przez „dzikich”, przed którymi Liberyjczycy odczuwają silny lęk, mimo że nazywają ich: „nasi pogańscy bracia”. Liberia powstała dzięki prywatnym organizacjom filantropijnym złożonym głównie z Amerykanów, finansowane są one przez kraje skandynawskie i Anglię; różnorakie Kościoły i misje liberyjskie zostały sprowadzone z Ameryki. 110 organizacji w 1829 roku zajmowało się przesiedlaniem Murzynów z Antyli i Stanów Zjednoczonych. Interesująca jest szczegółowa historia kolonizacji, ponieważ widzimy w niej przeważającą rolę białych: doktor Ayres, Jehudi Ashmun, założyciel stolicy, Monrowii, Buchanan, założyciel Grand-Bassa, Harper - Cape Palmas, Finley, założyciel Granville. W roku 1832 było w Liberii już 2500 czarnych. W roku 1847 zgromadzenie przedstawicieli czterech okręgów ogłosiło niepodległość Liberii, opracowało konstytucję, wzorując się na dokumencie Stanów Zjednoczonych, i wybrało prezydenta republiki, Mulata, J.-J. Robertsa. Kolejny prezydent, Benson, był również czarny; obaj należeli do rodziny pierwszych emigrantów. Od tamtej pory prezydenci byli zawsze Murzynami.

I właśnie od momentu, w którym biała część populacji utraciła swoją faktyczną przewagę, rozpoczęła się regresja kulturalna i mentalna. Duma lokalna jednak tylko rosła. Celem przodków Liberyjczyków było d o r ó w n a n i e białym; w Stanach Zjednoczonych, gdzie z tą ambicją nadal się spotykamy, biali walczą z nią za pomocą powszechnych środków: wydzielone wagony, windy, hotele itp. dla „kolorowych". Wydaje mi się, że z dokładnych relacji dotyczących przestępstw popełnianych przez Murzynów, głównie kradzieży, wynika, iż wzięcie siłą białej kobiety jest często jednym ze środków, poprzez który amerykański Murzyn chce ujawnić swoją „wartość rasową"; tym samym najbardziej gwałtowny gest, a w szczególności ten o najpoważniejszym wydźwięku, staje się wyrazem buntu przeciw domniemanej wyższości antropologicznej białych.

Jednak Liberyjczycy dawno już przeszli przez ten etap: w swoich oczach okazali się równi białym i teraz nimi pogardzają. Tak więc poprzez normalne przewartościowanie tłumaczy się fakt, że każdy Liberyjczyk, bez względu na to, czy jego karnacja jest oliwkowa, czy w następstwie mieszania się ras prawie biała, nazywa siebie dumnie c z arn y m [Negro].

Ale tej nazwy nie stosuje się wobec tubylczych plemion Murzynów: liberyjscy potomkowie Murzynów amerykańskich uważają czarnych z głębi kraju i z pobliskich kolonii za „pogańskich braci”. W taki sposób iluzjonizm społeczny łączy się z iluzjonizmem religijnym: pierwszym krokiem do przyjęcia do grupy rządzącej musi być przejście na chrześcijaństwo. Chrześcijaństwo liberyjskie jest jednak formalne: to zabawna mieszanka praktyk i idei pochodzących z różnych źródeł; od Palestyny po Anglię, Stany Zjednoczone, aż do Liberii droga jest długa, a przemiany nieuchronne. Do tego stopnia, że istnieją w Liberii misje protestanckie, których celem wydaje się nie tyle nawrócenie „biednych pogańskich braci”, ile utrzymanie Liberyjczyków w stosunkowo niezdegenerowanym chrześcijaństwie.

Oczywiste jest, iż Liberyjczycy, w związku z tym, że widzą siebie jako c z a r- 
ny ch i chrześcijan, chcą być również cywilizowani. W oczach obcokrajowców ich dziwny lokalny bowaryzm przejawia się najlepiej w formie ich cywilizacji. Pierwsi wodzowie zastosowali w Liberii zasady, których wykonalność była niewątpliwie możliwa w prosperujących przemysłowo i handlowo Stanach Zjednoczonych. Szczególnie poprzez różnicę w wynikach wyraża się słuszność następującej perspektywy: metody są warte tyle, ile warci są ci, którzy je stosują. Biali wznieśli miasta, domy, pomniki, drogi, wznieśli wszelkiego rodzaju budynki rolnicze, przemysłowe, handlowe w stylu amerykańskim i europejskim.

Pierwsi osadnicy z Ameryki pracowali w Stanach Zjednoczonych jako niewolnicy na plantacjach; po okresie walk założyli małe gospodarstwa, w których poświęcali się uprawie miejscowej kawy, zwanej „kawa z Liberii” [café de Libéria], dzikiej, ale z czasem coraz bardziej ulepszanej.

Ich kawa, dobrze przygotowana, dobrze oczyszczona, delikatnie wypalona, dobrze wyselekcjonowana, była ceniona na rynkach europejskich i dobrze się sprzedawała; i należy do jednej z najbardziej znanych.

Powiększono jednak nadmiernie rozmiary plantacji, nie bacząc na to, że rąk do pracy - potrzebnych licznie przy tego rodzaju uprawach - nie przybywało proporcjonalnie. Za późno zbierano ziarna, źle wyschnięte psuły się; mieszano złe z dobrymi; wysyłano do całej Europy; nikt ich nie chciał; kawa z Liberii straciła całe uznanie i została zdeklasowana; plantatorzy byli zrujnowani, plantacje opustoszały. Kawowce zaś powróciły do stanu dzikiego. W okolicach Monrowii znajdują się ruiny gospodarstw, porzucone młyny, szpalery olbrzymich kawowców opanowane przez liany i ciernie. Jeśli chodzi o inne uprawy, Liberyjczycy prowadzą je w równie prymitywny sposób, jak ich „dzicy” sąsiedzi.

To samo dotyczy przemysłu: stary Cooper ${ }^{8}$ budował statki wielorybnicze i szkunery; ale nikt nie poszedł za jego przykładem.

Biali Amerykanie wytyczyli aleje w Monrowii, wyrosła jednak na nich trawa, co spowodowało, że stały się one ulubionym pastwiskiem dla wszystkich wołów ze stolicy; spacerowanie tam nocą bez latarni jest niebezpieczne, pełno dziur, studni, brył granitu, które burzą monotonię drogi. Ulice schodzące na wybrzeże stały się potokami; tu i ówdzie widzimy słupy, które wspierały latarnie; parę latarni istnieje nadal, jeśli nawet tylko częściowo, ale w odróżnieniu od tych stojących przed niektórymi domami zamieszkałymi przez Europejczyków, Delafosse nie widział nigdy, żeby się paliły. Na wsi są drogi wytyczone przez plantatorów niemieckich. W Monrowii znajdują się bulwary nadbrzeżne zbudowane przez pierwszych osadników: „następne pokolenia nie starają się nawet o nie dbać”. Na mapach została zaznaczona latarnia morska; rząd francuski przekazał niezbędne lampy; jednak wysokość budynku nie przekroczyła nigdy 2 metrów, więc latarnią na mapach jest lampa naftowa na skośnym drewnianym palu. A żerdź służy za semafor.

Izba Przedstawicieli mieści się w dużym prostokątnym budynku bielonym wapnem:

zewnętrzne kamienne schody prowadziły onegdaj do biur ministra spraw zagranicznych i finansów, znajdujących się na pierwszym piętrze; jednak z powodu złej konstrukcji schody za-

8 Randolph C o o p e r - obok Elijaha Johnsona - jeden z założycieli Liberii, tj. jeden z niewolników amerykańskich wysłanych do Liberii. [Przypis tłum.]. 
waliły się; nigdy ich nie odbudowano i od wielu lat Ich Ekscelencje udają się do swoich biur wchodząc po czymś, co przypomina drewnianą drabinę.

Co się tyczy armii i marynarki wodnej, te znów są naprawdę zadziwiające. Mundury zdają się nie z tej ziemi, podobnie jak broń: żołnierze noszą strzelby wszystkich możliwych rodzajów, a ci, którzy podczas przejazdu władz ich nie mają - prezentują patyk. Do Liberii należą dwie strzelnice: obie zasypane na wybrzeżu Kru.

Stroje obowiązują, oczywiście, na modłę europejską, aż do przesady. Prezydent po odczytaniu Izbom swojego corocznego orędzia zaprasza najwyższych urzędników Republiki i akredytowanych przedstawicieli władz zagranicznych na wielki lunch mając do dyspozycji w sumie dwa krzesła dla wszystkich i wyszczerbione karafki: surdut bądź frak są jednak obowiązkowe.

To tylko niektóre spośród wielu zabawnych faktów, które odnotował z powagą Maurice Delafosse. Próbował wytłumaczyć sobie ten ciekawy fenomen prawdziwej cywilizacji, która w chwili narodzin miała wszelkie szanse na odniesienie sukcesu, a wystarczyło sześćdziesiąt lat, aby zredukować ją do żałosnego szkieletu. Teoria Delafosse'a jest następująca:

ogólnie wszyscy murzyni ${ }^{9}$, a Liberyjczycy w szczególności, podatni są na ulepszenia i postęp, ale te ulepszenia i postęp zostaną gwałtownie zahamowane, jeśli będzie się próbowało skierować je na tory naszej europejskiej cywilizacji.

Przed udaniem się do Liberii Delafosse żył przez kilka lat wśród „niecywilizowanych" murzynów na Wybrzeżu Kości Słoniowej; zauważył wtedy, że gesty Liberyjczyków przestają być śmieszne w momencie, gdy nie są wykonywane przez murzynów ubranych w europejski i pretensjonalny sposób, ale przez rdzennych mieszkańców, siadających na ziemi i podających się za tych, którymi naprawdę są.

Otóż, co ciekawe, Liberyjczycy chcą być właśnie inni, niż są. Nie narzuciła im tego zewnętrzna cywilizacja, której doświadczenie okazuje się za ciężkie na ich barki, ale, w rzeczywistości, ich bowarystyczna racja bytu. Ta iluzja doprowadza ich do śmierci..., lecz zarazem sprawia, że żyją. Może się wydać dziwne mówienie o nich jako o wykorzenionych, jednak oni nimi właśnie są. Ich przodków wyrwano z ojczystego środowiska zbyt gwałtownie, aby po powrocie do kraju protoplastów mógł nastąpić proces readaptacji. Prawdziwie zaadaptowani są ci, którzy pozostali w Stanach Zjednoczonych, w środowisku umysłowym i kulturalnym, przeciw jakiemu walczyli tylko po to, aby zdobyć do niego dostęp. Liberyjczycy natomiast nie mają przed sobą takiej przeszkody.

Upadek kulturalny jest widocznym znakiem wewnętrznej dysproporcji między koncepcją bowarystyczną a rzeczywistą psychiką. O tym, że to zamierzona teoria, świadczy system edukacji w Liberii: to kraj, w którym znajduje się najwięcej szkół dla obu płci, nawet w najmniejszych osadach. W praktyce - nie ma uczniów, a nauczyciele z ledwością potrafią pisać. Pewna liczba Liberyjczyków, którzy kształcili się w Anglii, Stanach Zjednoczonych lub w Sierra Leone, jest naprawdę wykształconych. To oni są teoretykami i obrońcami bowaryzmu liberyjskiego. Nie

9 W cytacie tym oraz następujacym po nim akapicie zachowuję oryginalną pisownię - małą literą - słowa „Murzyni”. Van Gennep, stosujący zawsze wielką literę, używa odmiennej pisowni, gdy cytuje Delafosse'a i parafrazuje jego spostrzeżenia. [Przypis thum]. 
tak dawno temu założyli uniwersytet, gdzie nauczało się języków [nowożytnych], greki, łaciny, hebrajskiego, historii powszechnej, teologii, nauk ścisłych. Ale po kilku latach uczniowie się znudzili i dziś budynek popada w ruinę; węże wiją gniazda w salach, puszcza opanowała wykłady. I teraz już jedynie gazety utwierdzają Liberyjczyków w ich iluzji.

Nie tylko Delafosse zdawał sobie sprawę z niebezpieczeństwa, jakie kreuje ta iluzja. Oto w jaki sposób wyrażał się niedawno wysoki kolonialny funkcjonariusz angielski, Sir H. H. Johnston ${ }^{10}$, który także mieszkał w angielskiej Afryce Centralnej i w Ugandzie i który podobnie miał szansę zobaczyć z bliska „dzikich” Murzynów. Tak oto mówił o Liberyjczykach:

Aż żal budzi, jak bardzo anglosaski jest ich ideał... Chrześcijaństwo liberyjskie jest dokładną kopią ubezwłasnowolniającego chrześcijaństwa tak typowego dla Anglii od czasów purytańskich aż do nadejścia lepszego stanu rzeczy w połowie XIX wieku. Nauki chrześcijaństwa zostały przeładowane adoracją słowa ze Starego Testamentu, tak niezwykle nudnego, bezużytecznego i mało znaczącego... Nigdy nie dość powtarzać, że ideałem Liberyjczyków był do tej pory ideał Nowej Anglii, a nie Afryki. Mieszkając na zachodnim wybrzeżu Afryki, kierują oni swoją twarz i myśli w stronę wschodniego wybrzeża Ameryki Północnej, która z kolei odbija XVIII-wieczną cywilizację angielską.

A tak sir Harry kończy:

Stańcie się cywilizowanymi Afrykanami, a nie pseudo-Anglosasami. Uczcie się języków zachodnioafrykańskich, a nie hebrajskiego, greki i łaciny...

To wszystko są symptomy stanu ducha tak charakterystycznego właśnie dla bowaryzmu. Gaultier stwierdza:

Nietzsche [w Niewczesnych rozważaniach], w związku z określoną okolicznością i konkretnym przypadkiem, zadaje fundamentalne pytanie: w jakim stopniu wypada, aby ludzie kreowali się według wzoru swojej historycznej przeszłości, według wzoru historycznej przeszłości ludzkości?

Liberyjczyków w ogóle nie interesuje przeszłość ludzkości, tym bardziej ich własna, ale tylko przeszłość dwóch określonych grup, starodawnych Żydów i anglosaskich purytan. Tak oto ten konkretny przypadek okazuje się wyjątkowo ekspresywny poprzez swoją względną prostotę. W tym miejscu teoretyk zgadza się z badaczami, kierując w stronę pogrążonych Liberyjczyków alarmujący okrzyk: wzmocnijcie się poprzez powrót do surowej, acz potężnej, żywotności „braci pogan". Jednak po zastanowieniu się taka rada może nie wydaje się nadal aż tak dobra: byłby to kolejny powrót do kogoś innego, znowu imitacja, znowu osobliwy bowaryzm. Inteligentny Liberyjczyk, M. Blyden, wierzy, że ocalenie nadejdzie ze strony „szczęśliwego kompromisu między islamem a chrześcijaństwem”, czyli kompromisu bowarystycznego między dwiema fikcjami, co wydaje się lekarstwem prawie niemożliwym.

Pozostanie jeszcze - lecz te wydarzenia dzieją się same z siebie, w dniach ogólnie panującej i nieznośnej bolączki - rewolucja powszechna, która zerwałaby wszystkie kajdany i która pozwoliłaby na nowo odbudować specjalny ideał liberyjski i cywilizację. Ale czy ma się jakąkolwiek pewność co do tego, gdy w grę wchodzą „ucywilizowani” Murzyni? Wystarczy spojrzeć na Haiti!

${ }^{10}$ [H. H.] J o h n s to n, Liberia, 1907, 2 tom, nr 4. 
Należałoby sprawić, aby los Liberyjczyków był znany innym Murzynom, tym nadal półdzikim, i był dla nich ostrzeżeniem przed przyjęciem iluzji białych. Oni mają swoje własne, zaznaczające się poprzez systemy organizacji politycznej, ekonomicznej, sądowniczej, małżeństwa, stworzone specjalnie dla krajów tropikalnych. Na co mogą im się przydać formy cywilizacji opracowane w krajach o łagodnym klimacie? To, co jest do przejęcia od danej cywilizacji, to zewnętrzne elementy, przede wszystkim środki komunikacji i transportu. Hindusi podróżują koleją żelazną, ale przez to się nie zeuropeizują. Japończycy mają pancerniki: pozostaną jednak Mongołami, dopóki zachowają iluzjonizm oparty na buddyzmie i szintoizmie, będą naszymi niebezpiecznymi rywalami; przestaną być nimi w momencie, w którym spróbują zastąpić go naszym iluzjonizmem żydowsko-chrześcijańskim, grecko-rzymskim i germańskim.

Tak więc bowaryzm stanowi jednocześnie siłę, jak i słabość. Bowaryzm jest tym, co czyni półdzikich Murzynów z Gwinei silnymi i zdatnymi do życia, co sprawia, że chcą siebie takimi, jakimi są ${ }^{11}$; tym, co powoduje, iż Liberyjczycy czują się słabi, jest ich chęć bycia innymi, niż są w rzeczywistości.

Żeby dobrze zrozumieć powszechny zasięg przytaczanego tu konkretnego przypadku i jego wewnętrznego mechanizmu, najlepiej będzie zacytować następujący fragment Le Bovarysme:

Dla wszelkiego rodzaju grupy lub zbiorowości możliwość i niebezpieczeństwo postrzegania siebie innymi niż w rzeczywistości zachodzi w momencie, w którym pewna liczba osobników przeżywa fascynację obcym zwyczajem, zamiast poddać się sugestii zwyczaju przynależnego do własnej grupy. Od tej pory tak oto wspólnota jest podzielona: rzeczywistość życiowa przygotowała ją do pewnych zachowań, a niektórzy jej członkowie nakłonili ją do przyjęcia innych zachowań. W odróżnieniu od intymności psychologii indywidualnej łatwiej jest tu dostrzec zachodzącą krzywdę, ponieważ wyraża się ona poprzez podział między rozmaitymi członkami grupy, jedni pozostają wierni naśladowaniu dziedzicznego fenomenu, inni zaczynają imitować obcy model. Ten antagonizm wywołuje brak zgodności uczestniczenia we wspólnych wysiłkach i ta wyrządzona szkoda, tak jak w przypadku pojedynczych osobników, ma zarówno płytkie i komiczne następstwa, jak i konsekwencje dużo poważniejsze, dotyczące zmniejszenia ogólnej aktywności grupy, obniżenia energii zbiorowej, gorszej produktywności, bezsilności, aż w końcu całkowitego rozpadu ${ }^{12}$.

Liberyjczycy są na ostatnim etapie i nic nie wskazuje na to, aby sami odnaleźli wyjście z sytuacji, za którą nie ponoszą odpowiedzialności. Ich przypadek charakteryzuje wręcz tragiczna trudność. Ci, którzy narzucili im sposób, w jaki oni siebie kreują, nie stworzyli sami takiej koncepcji. To jest pożyczony strój, to z Anglii przywieźli go sobie do Ameryki. A w Anglii antagonizm miejscowych bóstw - celtyckich i germańskich z jednej, a chrześcijańskich z drugiej strony dostarczył wybitnego przykładu iluzjonizmu zbiorowego, który Gaultier dokładnie przeanalizował ${ }^{13}$.

${ }^{11}$ Na ten temat poleca się serię tomów wydanych z okazji Wystawy w Marsylii, przede wszystkim dotyczące Wybrzeża Kości Słoniowej i opracowania Clozela, Villamura, Delafosse'a, Thomanna, o niemieckim Togo - monografie autorstwa Klosego, Spietha, Westermanna itp.

${ }_{12}$ Loc. cit. [tj. G a u $1 \mathrm{t}$ i e r, Le Bovarysme], s. 96.

13 Van Gennep nawiązuje do czwartego podrozdziału rozdziału V, Le Bovarysme des collectivités: sa forme idéologique, cytowanej książki G a ulti e r a Le Bovarysme, wznowionej ostatnio przez Presses de l'Université Paris-Sorbonne. Bowaryzm angielski jest przykładem bowaryzmu à rebours: w którym ,idea powszechna [czyli chrześcijaństwo] po zderzeniu z silnym egoizmem 
Dopóki sami stosują wobec siebie bowaryzm, Anglosasi i Amerykanie pozostają panami gry. Używają tej właściwości na różnych płaszczyznach, wszystkich skierowanych na pierwotny cel: kontynuowania bytu. Jeśli ten niuans jest trucizną, to ten drugi się formuje i staje się automatycznie antidotum. Przeciwko truciźnie - Murzyni liberyjscy nie mają innego wyjścia, jak stać się najpierw dzikimi Murzynami.

Ale może jest już za późno. Zresztą cała biała rasa interweniowałaby natychmiast. Jest ona bowiem tutaj, żeby w ramach swojej „misji” „wprowadzić cywilizację". Amerykański niewolnik po tym, jak został ucywilizowany, nie ma już prawa do bycia „odcywilizowanym”. Dosięgnąłby majestatu swoich twórców, stałby się winien świętokradztwa ${ }^{14}$.

I właśnie tu teoria Gaultiera rzuca ostre światło na mechanizm kolonizacji, kolonizacji w różnych formach, mniej lub bardziej brutalnych, mniej lub bardziej udanych. Wchodzą tu w grę rozmaite elementy. Ale czynnik psychologiczny był przez wielu zaniedbywany, wręcz umyślnie lekceważony. Istnieje też adaptacja psychologiczna, która jest brana pod uwagę w kontaktach indywidualnych, jednak pełni najistotniejszą funkcję w kontaktach zbiorowych.

Zmuszając Murzynów z krajów tropikalnych lub mieszkańców Oceanii do uznania naszego pojęcia wstydu, czyli do ubierania się, uśmiercamy ich. To przypadek brutalny, w którym wrodzona fizjologia i psychologia zabijane są za jednym zamachem. Zwykle nasz wpływ psychiczny nie wyraża się poprzez jedną znamienną czynność. Procesy zachodzą najczęściej stopniowo, gesty i sposoby czucia się tubylcem zmieniają się, antagonizmy indywidualne i wspólnotowe wzmacniają, grupy rozwiązują się i umierają. Nowa koncepcja świata, niszcząca koncepcję lokalną, przenika powoli.

Niektóre grupy przeciwstawiają naszym wpływom różne formy oporu, psychiczne i społeczne. Przed Murzynami z Sudanu, z Gwinei i z francuskiego Konga Północnego staje niezwykle silne narzędzie oporu: islam. W tym przypadku iluzja pochodzi również z importu: ale wydaje się łatwo przyswajalna przez Murzynów, Tatarów, Hindusów i Chińczyków, jeśli się patrzy na postęp islamu w Afryce i na fakt, że muzułmanin nigdy nie przejdzie na chrześcijaństwo, ale wielu

[czyli rdzennymi wierzeniami pogańskimi, germańskimi, celtyckimi Anglosasów] zostaje pomniejszona do funkcji środka, a jej użyteczność jest wypaczona i wykpiona" [staje się m.in. ważnym elementem władzy królewskiej] (,où l'idée genérale, aux prises avec un égoïsme puissant, est ravalée à n'être qu'un moyen et se voit par-delà son utilité, dénaturée et bafouée", ibidem, s. 65). [Przypis thum.].

${ }_{14}$ Zostało to opisane w tekście Rapport przez kapitana C. B. Wa 11 is a, konsula Wielkiej Brytanii w Monrowii na rok 1906 do spraw handlu itp. - w Liberii (Dipl. And. Cons. Rep., Annual séries, nr 3750), w książce Sir H. H. J o hn s to n a Liberia, t. 2, nr 4, 1907, w artykule M. D e l a fo s s e'a Le Liberia en 1907, w informacjach kolonialnych i dokumentach opublikowanych przez Comité de l'Afrique Française, nr 11 (XI 1907) i nr 12 (XII 1907). Nie sądziłem, że do tego stopnia będę miał rację. Anglicy specjalnie położyli rękę na finansach liberyjskich, reorganizując bank i sytuację ekonomiczną. Zostały stworzone wielkie kompanie (Liberian Development Co. i Liberian Rubber Corporation) i obie są zarządzane przez J. F. Brahama, „Anglika, powiedziałbym, sfrancuziałego". Nie ma sensu wchodzić w szczegóły: Liberia wraca do punktu wyjścia i to biali eksploatują teraz kraj, to biali czują się dobrze w swojej własnej cywilizacji, za ciężkiej i za bardzo usystematyzowanej jak dla Murzynów liberyjskich, nie potrafiących nawet, jak zauważyliśmy to niedawno, wytyczyć własnych granic, przez co byli zmuszeni wezwać do pomocy holenderskich topografów. 
chrześcijan nawraca się na islam. Dlaczego w Afryce i Azji, mniej w Europie, islam przoduje nad chrześcijaństwem? To jeszcze szerokie pole do badań, z którego niewiele użytecznych elementów zostało zebranych. Grupa Murzynów przechodzących na islam, jak najdalsza od rozpadu, utrzymuje i wzmacnia swoją siłę, utwierdza się.

Nasza koncepcja świata, nasz bowaryzm mało interesuje muzułmańskich Murzynów: mają swoją wizję, o której marzyli, za którą podążają, którą żyją. I która sprawia, że żyją.

Jeśli chcielibyśmy zastosować teorię Gaultiera do przypadków równie konkretnych, należałoby podjąć zagadnienie Metysów. Byłoby absurdem utrzymywanie starej definicji, zgodnie z którą Metys ,dziedziczy jedynie wady swoich rodziców”. Gdyby tak było, jeśliby się nadało słowu „wady” wymiar nie tyle etyczny, co biologiczny, ludzkość przestałaby już istnieć. Od tysięcy lat ludzkość bowiem jest $w$ ruchu, grupy przemieszczają się i mieszają, nie ma już na świecie żadnego regionu z „czystą rasą”. Ale ta źle sformułowana uwaga okazuje się prawdziwa w tym sensie, iż Metysi stanowią teren konfliktu między tendencjami mniej lub bardziej przeciwstawnymi i licznymi. To skomplikowany byt, co nie oznacza, że jest niezdatny do życia, nie umie produkować. Poszczególne przypadki stanowią tu wyjątkowo wdzięczne pole do studiów. Interesujące byłoby jednak zbadanie wspólnot, np. niektórych grup francuskich, angielskich Czirokezów z Ohio, Malezyjczyków z Indii Holenderskich, japońskich Ajnów, Rosjan wywodzących się od Tatarów, Mongołów itp. Niewątpliwie mogliby oni stwierdzić, że „zdolność postrzegania siebie innymi" odegrała ważną rolę w formowaniu i utrzymywaniu wspólnot i ich cywilizacji.

Z francuskiego przełożyła Zuzanna Krasnopolska (Uniwersytet Warszawski)

\begin{abstract}
A b stract
ARNOLD VAN GENNEP

\section{ON A FEW EXAMPLES OF COLLECTIVE BOVARISM}

As based on Jules de Gaultier's writings, a French ethnographer Arnold van Gennep decided to examine the presence of collective bovarism in the people of African republic of Liberia - black immigrants from the Antilles and the United States of America, conflicted with native Africans ("pagan brothers"). Their collective bovarism came into light as persistent following the American and European ideals and as gradual removal from indigenous traditions which, in spite of beliefs and desires, failed in gaining a new and better identity, but rather led to losing their own identity and exposed at ridicule in the eyes of the world. In his thorough analysis of Liberian habits, economy, agriculture, industry, policy, and even fashion, van Gennep tracks a successive decline of culture, urging to fight for regaining their own identity.
\end{abstract}

